\title{
Representing the War. Early Twentieth Century Maps and Models in the Fonds of the Italian War History Museum in Rovereto
}

\author{
Elena Dai Prà ${ }^{\mathrm{a}}$, Valentina De Santi ${ }^{\mathrm{a}^{*}}$, Giannantonio Scaglione $^{\mathrm{a}}$ \\ ${ }^{a}$ Geo-Cartographic Centre for Studies and Documentation (GeCo), University of Trento, Elena Dai Prà - elena.daipra@unitn.it, \\ Valentina De Santi -valentina.desanti@unitn.it, Giannantonio Scaglione-g.scaglione@unitn.it
}

* Corresponding author

\begin{abstract}
The representation of the areas in which some of the most significant events of the First World War took place has produced a wide range of materials, such as cartography, aerial and terrestrial photos, textual descriptions and field surveys. In addition, war events were also represented through three-dimensional models. Topographic maps and models constitute composite figurations, which are rich in informative data useful for the preservation of the memory of places and for increasing the knowledge of cultural heritage. Hence, these sources need to be studied, described, interpreted and used for future enhancement. The focus of this paper are archival materials from the collections kept at the Italian War History Museum of Rovereto (Museo Storico Italiano della Guerra), in the Trentino-Alto Adige region. Firstly, we will investigate the cartographic fond in order to assess the composition and origin of its materials. Secondly, we will present the Museum's collection of Early-Twentieth Century models. Such precious heritage is not yet part of an exhibition, and is kept in the Museum's warehouses. The paper constitutes the occasion to present the initial results of a still ongoing project by the Geo-Cartographic Centre for Study and Documentation (GeCo) of the University of Trento on the study and analysis of two archival complexes preserved in the abovementioned Museum. In particular, the paper focuses on the heuristic value of such representational devices, which enable an analysis of the different methods and languages through which space is planned and designed, emphasizing the complementarity between different types of visualization.
\end{abstract}

Keywords: Military Cartography; Topographical Models; First World War; Trentino.

\section{Introduction: From Strategic-Operational Documents to Historical Heritage Sources}

The representation of the portions of the Earth's surface where some of the most significant events of the First World War took place has resulted in the production of a wide range of materials, such as maps, paintings, prints, aerial and terrestrial photos, textual descriptions and field surveys. The importance of military archival sources, not just for a chronological history of war operations but for a broader analysis capable of contributing to social and geographical history is well-established (Fontana, Pisetti, 2019). In particular, with respect to the cartographic production relating to the First World War, an important line of research has consolidated itself over the last decades, aimed at expanding existing knowledge. Hence, scholars have addressed cartographic production processes, the language of maps and the application of new digital investigation tools to the study of such documentation (Dai Prà, Gabellieri, 2020; Masetti, 2018). Visual descriptions of the war were also made through the production of models, i.e. of valuable threedimensional representations (Bürgi, 2007). In the wake of a tradition of such representations of terrain, which is not just military (Corvisier 1993; Faucherre, Monsaingeon, Roux, 1989), the models of the Rovereto museum seem to have been created for the use of main military commands and for purely strategic purposes. They were aimed at visualizing the topographical configuration of the territory that had to be defended or attacked (Ceola, 1925). 
Cartographic and plastic topographical representations of territories constitute composite figurations, loaded with informative data useful for the preservation of the memory of places and for increasing the knowledge of the cultural heritage to be studied, described, interpreted and included in adequate and future enhancement plans.

In the next paragraphs we will examine two specific collections, that of maps and that of models. These are only two of the numerous collections of the Italian War History Museum in Rovereto, one of the most important and well-known Italian institutions dedicated to the First World War (Antonelli, et al., 2020). The museum was established in 1921 as a 'national monument', finding its seat within the castle of the town of Rovereto. Its purpose was to preserve the historical memory of war events of the early Twentieth Century. However, later on, it was also used for nationalist political propaganda (Rasera, Zadra, 2001) (Figure 1).

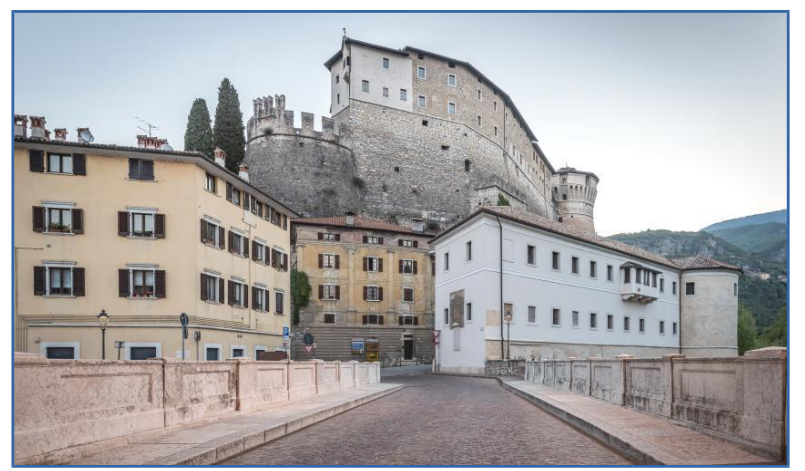

Figure 1. Rovereto Castle, seat of the Italian War History Museum

The Geo-Cartographic Centre for Study and Documentation (GeCo) of the Department of Humanities of the University of Trento is carrying out research on the materials kept at this institution, with the aim of studying and enhancing them, considering them both as geohistorical sources and as heritage to preserve and promote. In particular, the intent of our paper is to shed new light on these important materials, focusing on the heuristic value of such representational devices, which allow the interrogation and analysis of the different methods and languages through which space is represented, underlining the complementarity between different types of visualization.

\section{The Italian War History Museum of Rovereto}

\subsection{The Cartographic Fund}

The cartographic collection preserved in the Museum constitutes one among the richest corpora, which has so far lacked an adequate, organic and detailed study. In order to investigate the size, composition and origin of these materials, the research will aim at contextualizing this heritage: projects, reports, letters, accounting documents will allow us to reconstruct the process of cartographic production and, thus, analyze the purposes and languages and, where possible, the professional training of their authors. It will thus reconstruct the 'preparatory stages' essential for any reading of a map (Rombai, 2010).

To date, the Museum's cartographic documentary heritage consists of approximately 6,000 military cartographic units, of which 4,600 have already been catalogued and can be consulted online on the Trentino Library Catalog (Catalogo Bibliografico Trentino, CBT) ${ }^{1}$. The provenance of such documentation varies. Maps have often reached the Museum together with artefacts of different nature, and have scrupulously been recorded in special Quaderni (Notebooks) since the establishment's foundation. The main core of the collection consists in donated maps. In most cases, donations were private and helped create a dense network of voluntary events aimed at celebrating the memory of the war under a single authoritative museum aegis.

Through the analysis of the numerous notebooks initially written by Mario Ceola, director of the Museum between 1922 and 1939, it is possible to reconstruct the events that led to the progressive formation of the different cartographic complexes that were gradually collected by the Museum. In the very first years, major contributions came from small initiatives by private individuals such as Carlo Maccani from Avio, who, in 1922, donated several maps: the Trentino Military Map (Dolomites, Lombard Alps and Lake Garda); the Military Map of the Western Dolomites; the Military Map of Trento; the Military Map of Cles (Figure 2).

Continuing to scroll through the pages of these notebooks, it is easy to notice how over the years, in addition to private contributions, which have increasingly grown and constitute the main part of the Museum's cartographic fund, conspicuous donations from important public institutions have begun to arrive. An example are the sixty-three War Front Maps of the Military Geographical Institute of Florence in 1939 or the fiftythree maps donated by the Civic Museum of Rovereto (Figure 3). The participation of authoritative national cultural institutions is no coincidence, their aim was to enrich the well-organized and "successful" exhibition itineraries: "In the two decades since its opening until

\section{$1 \mathrm{https} / /$ strutture-}

provincia.primo.exlibrisgroup.com/discovery/search? vid=39SBT_INST:39SBT_VU1\&lang=it [10/06/2021]. 
1941, the Museum was visited by over four hundred thousand visitors, a rather impressive figure" (Barozzi, 1971). Thus, it has not simply become a model, but a homeland museum capable of collecting national war identity.

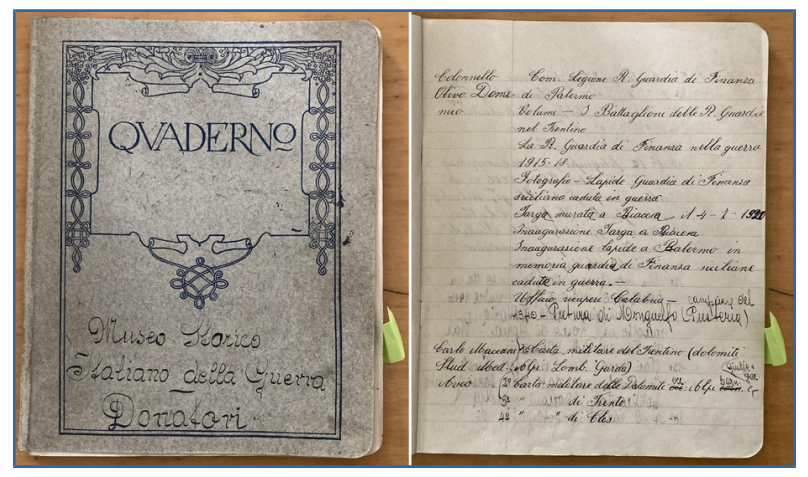

Figure 2. Museo Storico Italiano della Guerra, Fondo Donazioni, 1922-1969, Quaderno Donatori 1922, p. 1.

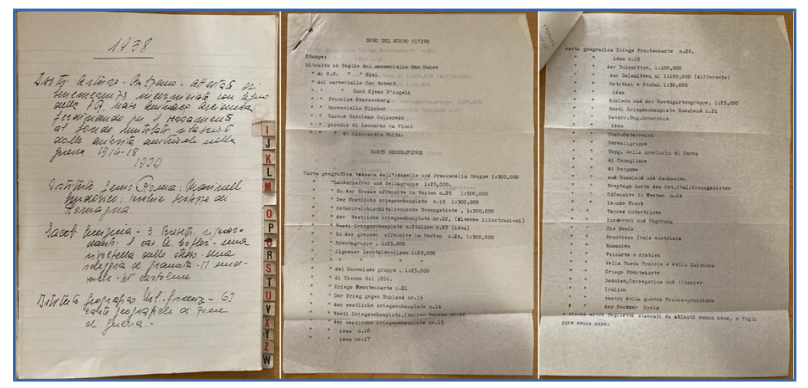

Figure 3. Museo Storico Italiano della Guerra, Fondo Donazioni, 1922-1969, Quaderno Donatori 1932-1939 (to the right); Elenco delle donazioni del Museo Civico di Rovereto (in the middle and to the left).

Through the available lists of documents and the indications therein contained, it is also possible to reconstruct the specifications of many cartographic sources. In recent years, the Museum's collection of historical maps has welcomed a large number of Austrian-made documents - a direct evidence of recent history - representing the war events disputed between the Italian and the Habsburg armies. The documents donated by General Tullio Marchetti ${ }^{2}$, arrived at the

2 Tullio Marchetti was born in Rome on 7 November 1871. His family, originally from Trentino, played a notable role in the events of the Risorgimento. He attended the Military Academy of Modena, obtaining the rank of second lieutenant in the $\mathrm{V}$ Alpini Regiment in 1891. In 1892 he began his activity as a military informant for the Command of the V Alpine Regiment of Milan and then for the Command of the III Corps of Milan. In 1902, while remaining in the $\mathrm{V}$ Alpini Regiment, he was assigned to the Information Office of the Command of the Army Staff Corps, dealing with Trentino and Tyrol. Starting from 1905, he worked on the drafting of geographical-military monographs, on the Trentino and South Tyrol mountain ranges and on the lines of operation. They destined for the Command of the General Staff Corps of Rome. Promoted to the rank of captain, in 1913 he was aggregated to the Military Monographs and Guides Office of the General Staff, active for the north-east front since 1911. In the autumn of 1914 he was assigned to the Information Office of the Military Command of Milan and subsequently appointed member of the Commission compiling the attack plans against Austria, which dealt with the Giudicarie valleys, Ledro valley, Riva, and Loppio. From 26 April 1915 he was called to head the Brescia Information Office, dependent on the Command of the Army Staff Corps and on behalf of this office he created a foreign information center. In May 1915 the Center passed, together with that of Verona, to the Command of the 1st Army (based in Milan) and to its Information Office, of which it became the branch responsible for the coordination of the foreign center with functions also of support to the Verona center in the collection of information for the area relating to the Giudicarie-Garda sector. In August the Center was dissolved, while that of Verona was absorbed by the Information Office I Army. In fact, Marchetti continued to direct the foreign center and to produce the news. In the same month of August he was promoted to major. On 25 May 1916 he obtained the rank of lieutenant colonel, and on 31 August he was appointed head of the Information Office of the 1st Army. In June 1917 he was promoted to the rank of colonel. Between the end of October and mid-November 1917, in the context of the events in Caporetto, Marchetti played the role of liaison officer between the Commands of the I Army and the III Corps and the Supreme Command based first in Udine and then in Treviso. On October 30, 1918, he was among the seven Italian plenipotentiaries in charge of stipulating the armistice with Austria-Hungary, which took place at Villa Giusti on November 3. After the end of the conflict, Marchetti continued to direct the Information Office of the Command of the 1st Army until its dissolution, on September 16, 1919; then he assumed the same post at the Area Command of Trento until his leave on 20 July 1920. In June 1926 he was promoted to brigadier general and on 7 November 1933 retired due to age limits. After the war he became a member of the Società di Studi Trentini (1926), of the Academia Roveretana degli Agiati (1927), of the Museum of Risorgimento in Trento, and actively collaborated with the Italian War History Museum of Rovereto (Fontana, 2020). 
Italian War History Museum in Rovereto in two distinct moments, in 1922 and in $1955^{3}$. These maps constitute one of the most important archival sources preserved in the historical archive of the War Museum. This is a documentation of great national importance that offers new suggestions and interpretations on the activity of collecting news relating to the defensive system and on the deployment of military forces of the AustroHungarian Army, which was carried out by the Information Office of the 1st Army during the ItalianAustrian war.

The deposit which took place in April 1922 was carried out by Marchetti himself in view of the opening of room 3 (the Marchetti room) in the Museum. It included: documentation produced by the Information Service of the Command of the 1st Army (news bulletins Cat. A, B, C; monographic studies on the Sugana valley, the Brenta river, the Avisio river, the Cismone stream, Rovereto and surroundings, the Giudicarie valleys, Plateaus); informative work on Trentino compiled by Marchetti before the war $(1906,1910)$; texts of two of his conferences (January 1915); documentation on the enemy's defensive arrangement in the Karst, Medio Piave and Carnia sectors (Fontana, 2020).

At the beginning of the 2000s decisive reorganization and inventory descriptions of the Marchetti maps were needed, which would restore, as far as possible, their unity, consistency and original articulation and would facilitate access to them by historians and researchers. Such actions were carried out as part of the fund reorganization project submitted in 2009 and co-financed by the Bank of Trento and Rovereto (Cassa di Risparmio di Trento e Rovereto).

Some of the most interesting maps representing the Pasubio region also belong to the Marchetti collection, through which we will try to reconstruct, at least in part, the image of one of the most significant places of the Great War. These representations, generally at a scale of

\footnotetext{
3 Among the materials that arrived at the Museum in 1922 there are also the papers produced in the 1870 s by Giovan Battista Adami, which he had found in 1892 in Edolo. These were displayed to the public. The main nucleus of the collection, donated to the Museum by the General's heirs upon his death, in 1955, was for a long time kept inside a chest and, after a preliminary reorganization carried out in the 90s, included in the miscellaneous collection "Information" together with papers from other sources. In reality, already at the beginning of the 1920 s, at the same time as the setting up of the room dedicated to him, Tullio Marchetti had donated to the Museum a large group of documents from his personal archive, consisting mostly of geographical maps and propaganda leaflets, later merged in the cartographic collection and in the thematic fund "Propaganda".
}

1:10,000, are capable of providing new and valuable information on the number of barracks and on the enemy's stationings between the months of August and September 1917 (Figure 4).

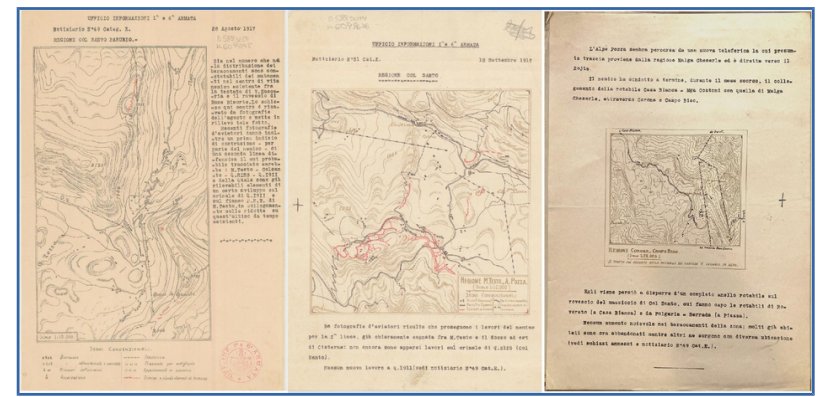

Figure 4. Museo Storico Italiano della Guerra, Archivi di persona, Fondo Tullio Marchetti, B. 6, 2.4 1.5-1.6, Ufficio Informazioni $1^{\wedge}$ e $6^{\wedge}$ armata. Notiziario $N^{\circ} 49$ Cat. E., 28 Agosto 1917, Regione Col Santo Pasubio (To the left); Notiziario No 51 Cat. E., 18 Settembre 1917, Regione Col Santo (In the middle and to the right).

The drawings, as explained in the Notiziari (news bulletins) were obtained from aerial photographs taken in the same period, thanks to which the dynamics of the enemy lines could be established with great precision. In particular, the Barracks, the abandoned Barracks, the underground shelters, the Observatories, the Muleteers, the route of the Teleferics, the Pitches for the gunners, the stakeouts in Caverns and the Trenches were highlighted using different symbols.

These iconographic materials constitute a heritage of the highest scientific and informative value for the study of war events, above all because they are still integrated or traceable to the documentation of origin, having never undergone arbitrary archival separation from the corpus to which they belong.

\subsection{The collection of models}

In addition to the very rich cartographic collection, at the Italian War History Museum in Rovereto there is an interesting collection of models, heritage that is still unexplored and whose study is in its early stages. The survey conducted to date has made it possible to gain knowledge of the collection and to define the lines of research through which we can start to study it.

First, we should emphasize that, unlike that of cartographic documentation, the study of such type of representation of geographical space, at both a topographical and a site scale, has very often received little attention. This despite the fact that this form of visualization can be considered a traditional means of representation, whose aims can be traced back to the conceptualization of scientific thought, propaganda and 
territorial planning; uses that meet both civil and military needs (Corvisier, 1993).

Almost all of the pieces that constitute the Museum's collection are currently not exhibited and kept in crates in the museum's warehouses (Figure 5).

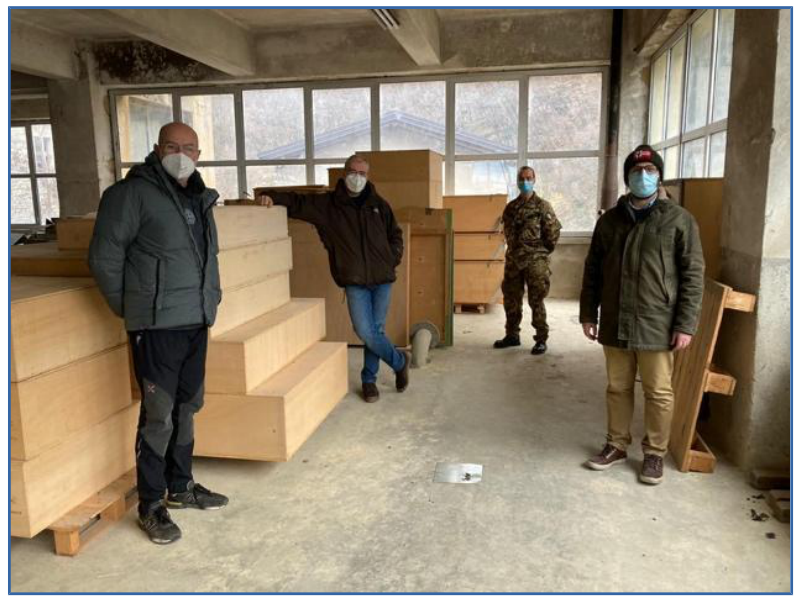

Figure 5. Italian War History Museum, inspection visit to the warehouses.

A preliminary investigation of these materials has focused on the historical guides of the museum, written between 1921 and 1971, through which it was possible to collect the first two nuclei of information, relating to the size of the collection and to the period of its display in the museum rooms ${ }^{4}$.

As for the Quaderni mentioned in the previous paragraph, the first guides consulted, those of the 1920s

41925 - Ceola Mario - Head of the War Museum, Guida del Museo Storico Italiano della Guerra in Rovereto (Trentino), Rovereto, Tipografia Manfrini\&C e Tip. Grigoletti, 1925. 1927 - Ceola Mario - Head of the War Museum, Guida del Museo Storico Italiano della Guerra in Rovereto (Trentino), Milano, Arti Grafiche Brambilla\&C., 1927. 1930 - Guida del Museo Storico Italiano della Guerra in Rovereto (Trentino), Rovereto, Tipografia Mercurio, 1930. 1932 - Ceola Mario - Head of the War Museum, Guida del Museo Storico Italiano della Guerra in Rovereto (Trentino), Rovereto, Tipografia Mercurio, 1932. 1934 - Ceola Mario- Head of the War Museum, Guida del Museo Storico Italiano della Guerra in Rovereto (Trentino), Rovereto, Tipografia Mercurio, 1934. 1936 - Ceola MarioHead of the War Museum, Guida del Museo Storico Italiano della Guerra in Rovereto (Trentino), Rovereto, Tipografia Mercurio, 1936. 1938 - Ceola Mario-Head of the War Museum, Guida del Museo Storico Italiano della Guerra di Rovereto (Trentino), Rovereto, Tipografia Mercurio, 1938. 1955 - Guida del Museo Storico Italiano della Guerra con notizie sulla campana dei caduti e l'ossario di Castel Dante, Rovereto, Arti Grafiche Manfrini, 1955. 1971 - Barozzi Giovanni, Guida del museo storico italiano della guerra di Rovereto, Museo storico della Guerra 1921-1971. and 1930s, were mostly written by Mario Ceola, director of the museum during his early years of activities ${ }^{5}$. The last ones, instead, date to 1955 - without author - and to 1971. If the guides drawn up between the 1920s and the late 1930s offer information on the models on display, the last two do not contain any reference to these artifacts. It can therefore be assumed that the models were no longer placed in any of the exhibition rooms and that from that moment they have been in the warehouses (Figure 6).

By reading such documentation it is possible to create a first indicative list of the pieces in the collection. In particular, we will devote our attention to the most geographic models and not to those aimed mainly at the creation of individual artifacts. "In order to get an exact idea of the area where the dependent troops fought, in order to further study the actions and to know our and the enemy's positions, evaluate their strategic or tactical importance, the possibility of conquest and the difficulties of the assault, the main commands (division, army corps, army) were supplied with models" (Ceola, 1927 , p. 69). These were designed to provide a visualization of the morphology of the land and its topographical configuration.

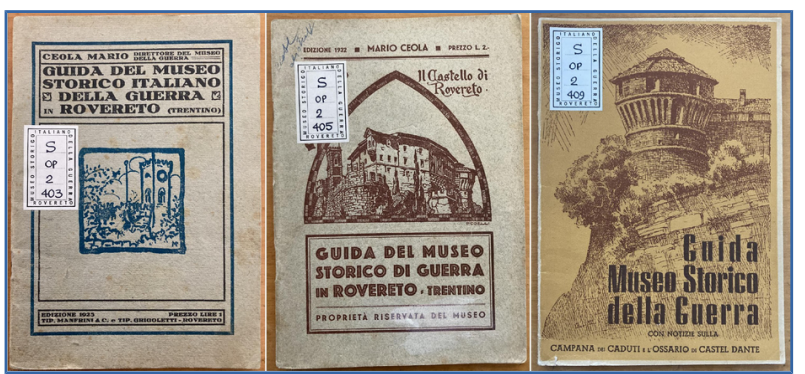

Figure 6. Museo Storico Italiano della Guerra, Archivio Storico, Frontespizi delle guide $(1925,1932,1955)$

The descriptions that the guides provide of the materials displayed in each of the different rooms that make up the museum's itinerary make it possible to draw a first list of the artifacts that are part of the collection. In the 'Rovereto room' is a model of the town and the destruction it suffered during the conflict. In the 'colonies room' are five models representing: the camp of a Libyan battalion; Eritrean ascarians; some forts and monuments of the colonies that highlight the glorification and

5 In the historical archive of the museum there is also a collection in his name, the Mario Ceola collection (1915-1945 with documents from 1865); one of the numerous fonds such as, among others, the Tullio Marchetti fond referred to in the previous paragraph. For a presentation of the fonds preserved in the historical archive of the Museum see Fontana N., 2014 e https://www.museodellaguerra.it/features/archivio-materiali/ 
propaganda function of these devices (Falcucci, 2020). The 'models room' exhibited the largest number of topographical scale models aimed at visualizing the shapes of the terrain (Figure 7):

- Val Giudicaria from Condino to Forte Por $(1: 10.000)$;

- Media Valsugana-Asiago plateau (1:25.000);

- Upper Val Posina-Pasubio-Upper Val Terragnolo (1:500);

- Monte Pasubio (1:2000).

- Vallagarina-Monte Baldo (1:5000);

- Plateaus between Monte Sisemol and Monte Valbella (1:1000);

- Montello (1:1000);

- Val Brenta-Monte Grappa (1:25000);

- Val d'Astico and the Asiago plateaus (1:25000);

- Vallagarina-Vallarsa-Val dei Ronchi-ZugnaBaffelan (1:10000);

- Val di Ledro-Riva (1:25000);

- Area from Garda to the Asiago plateau (1:25000);

- Monte Piana (1:500).

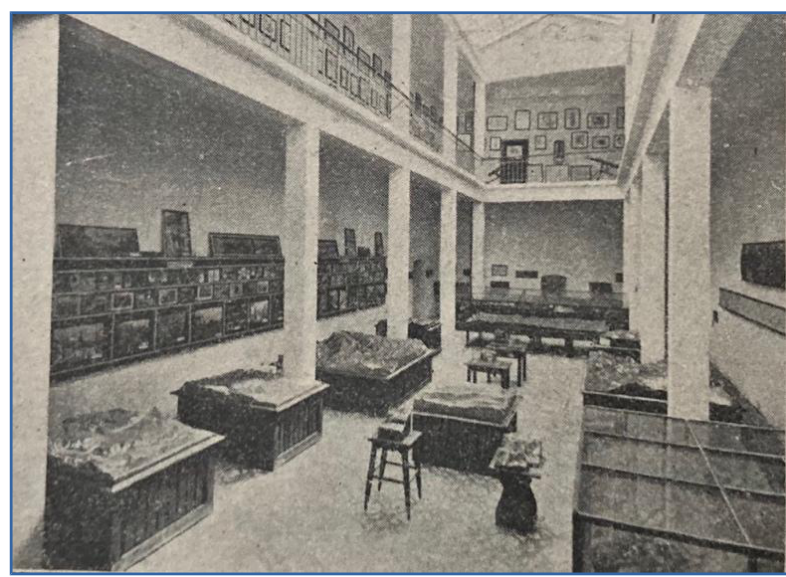

Figure 7. The 'Museo Storico Italiano della Guerra', Historical Archive, Guida del Museo Storico Italiano della Guerra in Rovereto (Trentino), Rovereto, Tipografia Mercurio, 1930, p. 26.

The study of these models is complicated by the scarcity of contextual sources directly attributable to them. However, the continuation of the research involves both the analysis of the administrative materials of the Museum and the study of their manufacturing processes. In this respect, the literature on topographical representation techniques of the time (instructions, manuals etc.) and on the connection with other still little known collections and deposits will also be addressed. Such study will allow to reconstruct the techniques, the skills of maps' and models' authors and the links with the planning of military strategies or with propaganda actions and / or celebration of war events.

\section{Notes on an Ongoing Case Study: The Representation of Pasubio Massif}

Following the presentation of the two funds, we would like to focus our attention on the case study of the representation of the Pasubio massif. This area constitutes a focal point of the operations that took place during the war. Moreover, as is well known, it is where Cesare Battisti was captured, an prominent Early-Twentieth Century figure in several fields of culture and knowledge, including that of geography, (Dai Prà, Gabellieri, 2021). This portion of territory was represented through multiple forms of visualization, particularly maps and models. Their study will allow, to give new light not only to the dynamics of the armed fronts, but also to the skills and the technical and geographical knowledge urged by war and elaborated in its context, with repercussions and echoes also on civil society.

Among the cartographic documents present in the museum's collections, which are worthy of further study, the maps that allow us to analyze the representations of the different military fronts are particularly valuable. Among these is the Austrian map no. 147 Pasubio from 1918, whose scale is 1: 10,000 (Figure 8). In addition to allowing a cross-reading of the territory of one of the most demanding battle theaters of the Great War, this map offers a detailed description of the movements and evolutions, in this case seen from the Austrian side, of the battle front around the massive mountain.

As already indicated in the previous list, a model of this area, produced by the Military Engineers and showing the Italian and Austro-Hungarian positions, was also made. In particular, it shows some writings such as "Cap.le Pugno 1918", the indication of the North, of the scale (1: 2000) and the representation in red and blue of the different alignments (Figure 9-10). 


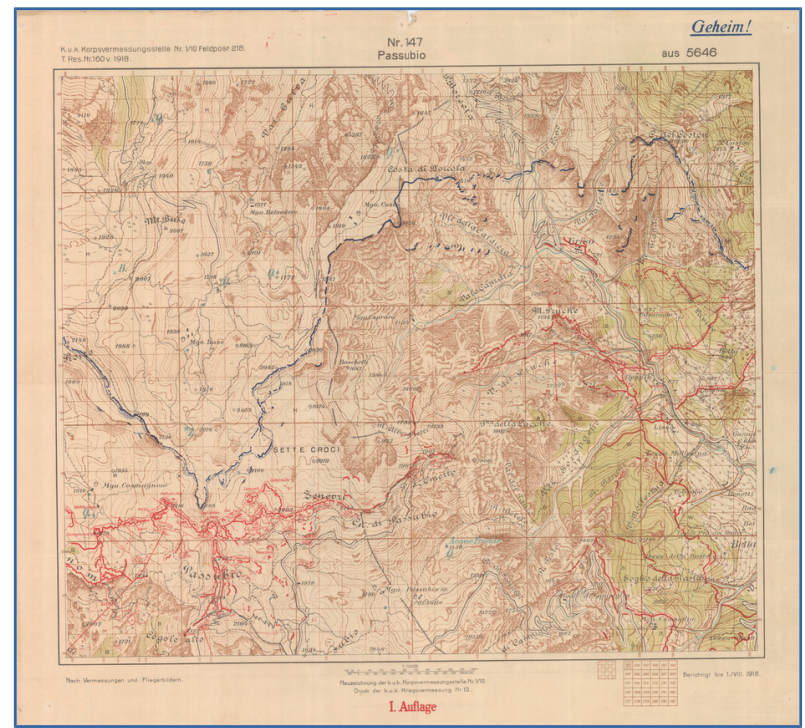

Figure 8. Pasubio: nach Fliegerbildern, Vermessungen und Truppenmeldungen, berichtigt bis 1/VIII.1918, Scala 1:10.000.

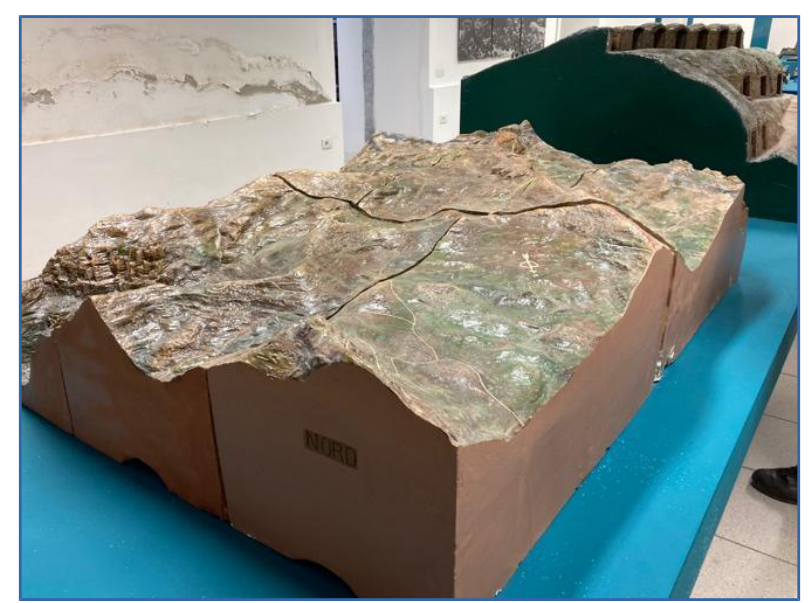

Figure 9. Museo Storico Italiano della Guerra, Armate in Miniatura. Collezioni del Museo della Guerra (Torbole).

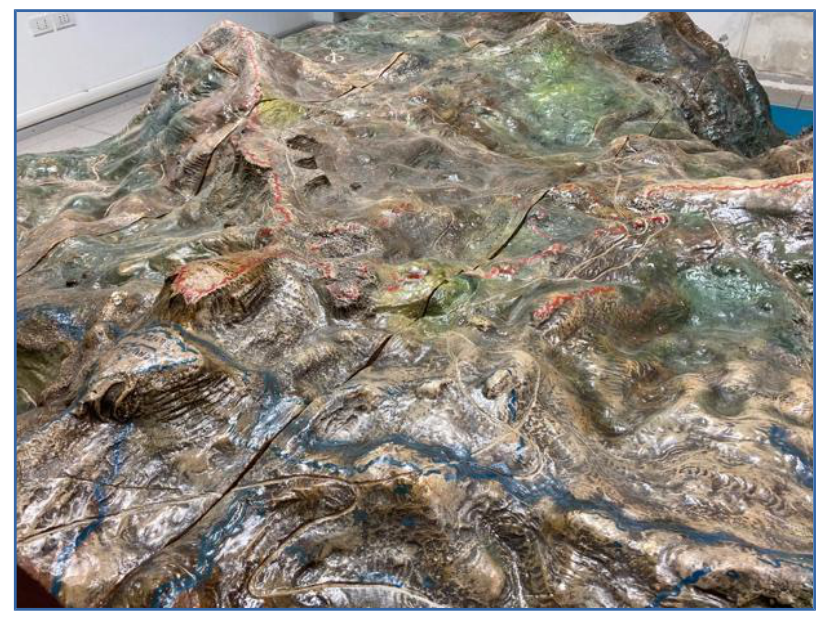

Figure 10. Museo Storico Italiano della Guerra, Armate in Miniatura. Collezioni del Museo della Guerra (Torbole).
If war events are more than known facts, it should be emphasized, however, that they have not yet been adequately addressed from a territorial perspective and using the geo-historical survey method. Let us not forget that, as Georges Duby has already explained, "history happens on the ground, and not just political history, but also that of institutions [...]. To develop his investigations, the researcher cannot go without geographical maps, since the geographical representation brings to light unexpected relationships between the facts he discovers" (Duby, 1992, p. 1). Based on these assumptions, the documentation relating to the case study will be collected within a single corpus and investigated. This will help to strengthen the identity of the places that recall or stage the memory of the Great War.

\section{References}

Antonelli, Q., Pise, A., Rasera, F. and Zadra, C. (dir. 2020). Cronache della guerra in casa. Scritture dal Trentino e dal Tirolo. 1914-1918, Rovereto: Museo Storico Italiano della Guerra, Accademia degli Agia, Fondazione Museo storico del Trenno.

Barozzi, G. (1971). Cinquanta anni di vita. Il Museo storico italiano della guerra di Rovereto. 1921-1971, in G. Fioroni (dir). La valle di Ledro nella Prima guerra mondiale (1915-1918), Trento: Edizioni Temi.

Bürgi, A. (dir. - 2007). Europa miniature. Il significato culturale dei rilievi plastici XVI-XXI secolo, Zurich: Verlag Neve Zurcher Zeitung.

Ceola, M. (2006). Pasubio eroico, Rovereto: Museo Storico Italiano della Guerra (1 ed. 1939).

Ceola, M. (1925). Guida del Museo Storico Italiano della Guerra in Rovereto (Trentino), Rovereto: Tipografia Manfrini\&C e Tip. Grigoletti.

Corvisier, A. (dir. - 1993). Actes du colloque international sur les plans-reliefs au passé et au présent, Paris: SEDES.

Dai Prà, E., Gabellieri, N. (2020), Mapping the First World War Forgotten Material Heritage: A Multi-proxy and GIS-based Proposal for the Trentino Alps, Defensive Architecture of the Mediterranean, vol XI: 883-890.

Dai Prà, E., Gabellieri, N. (2021). Bridging geographical research and political action: the Trentino Italian region in the scientific and socialist writings of Cesare Battisti, 1895-1914, Journal of Historical Geography, 71: 83-93.

Duby, G. (1992). Atlante storico. La storia del mondo in 317 carte, Torino: Società editrice internazionale.

Falcucci, B. (2020). Le sale coloniali del Museo della Guerra di Rovereto: censimento e storia delle 
collezioni, Annali Museo Storico Italiano della Guerra, n'28: 255-273.

Faucherre, N., Monsaingeon, G. and Roux (de), A. (dir. 1989). Les plans-reliefs des places du Roy, Paris: Éditions du Patrimoine, Biro Éditeur.

Fontana, N. (dir. - 2014). Guida agli Archivi, Rovereto: Museo Storico Italiano della Guerra.

Fontana, N. (2016). La regione fortezza. Il sistema fortificato del Tirolo: pianificazione, cantieri e militarizzazione del territorio da Francesco I alla Grande guerra, Rovereto: Museo Storico Italiano della Guerra.

Fontana, N., Pisetti, A. (2019). Archivi militari per gli studi storici sul Trentino tra Ottocento e la Grande Guerra, in Fontana, N., Pisetti, A. Archivi militari tra Ottocento e Novecento. Ricognizioni e acquisizioni, Soprintendenza per i Beni culturali, Ufficio Beni archivistici, librari e archivio provinciale/Museo Storico Italiano della Guerra di Rovereto: IX-XIII.

Fontana, N. (2020). Il fondo Tullio Marchetti, Annali, Museo Storico Italiano della Guerra, 28: 179-205.

Masetti, C. (dir. - 2018). Per un Atlante della Grande Guerra, Roma: Labgeo Caraci.

Pole, G. (dir. - 2012). La mia guerra in Vallarsa e sul Pasubio. Lettere a Giustino Fortunato, Rovereto: Associazione Il Chiese, Museo Storico Italiano della Guerra, Comune di Vallarsa.

Rasera, F., Zadra, C. (2001). Memorie in conflitto. La Grande Guerra nelle esposizioni del Museo della Guerra di Rovereto, Memoria e Ricerca, nº 7 : 15-38.

Rombai, L. (2010). Le problematiche relative all'uso della cartografia storica, Bollettino dell'Associazione Italiana di Cartografia, 138: 69-89. 